\title{
PARASITOLOGY
}

\section{Post-genomic progress in helminth parasitology}

\section{Submit your paper online}

\section{http://mc.manuscriptcentral.com/par}

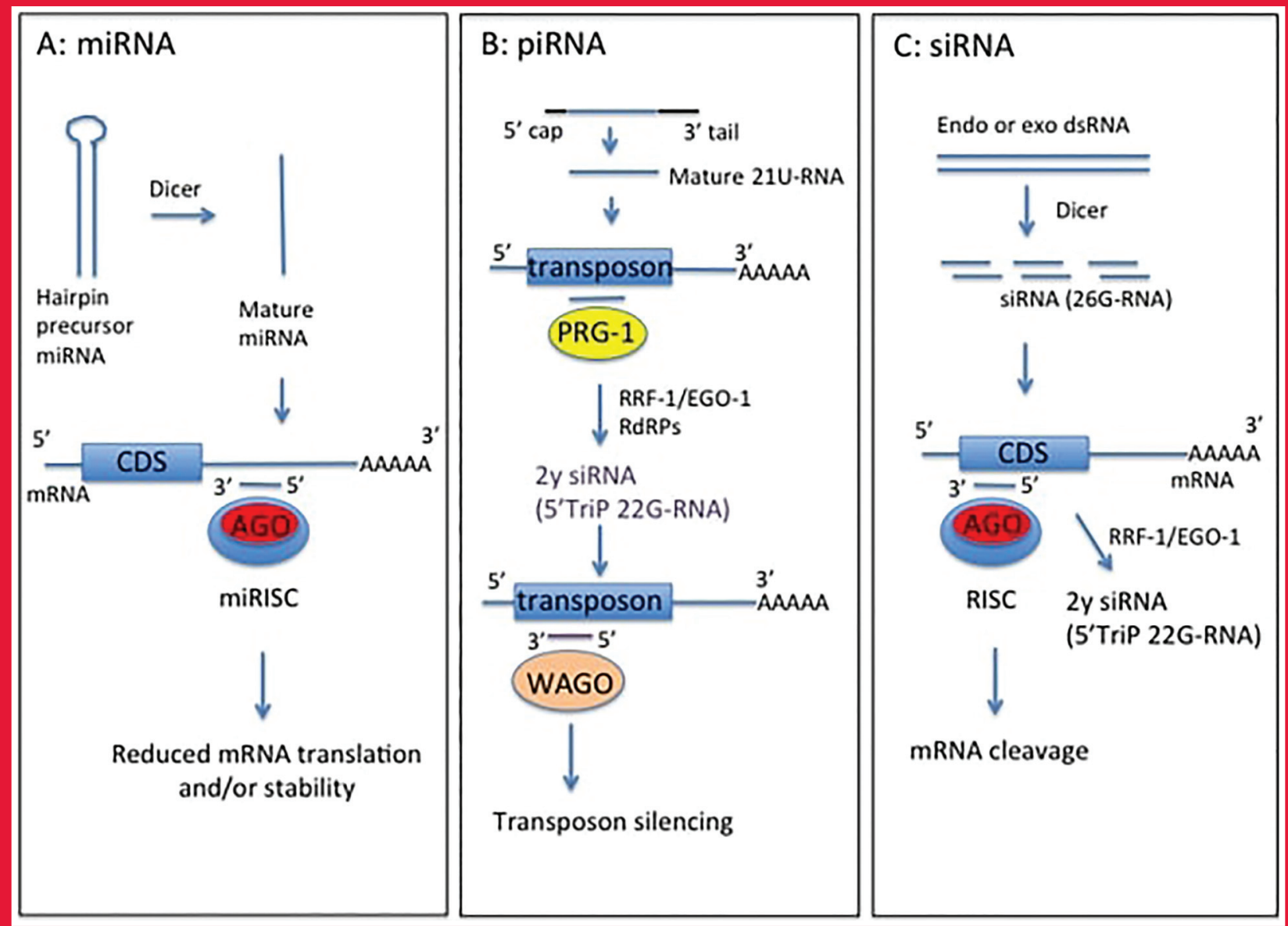

Guest Editor

Paul McVeigh

Co-ordinating Editor

J. T. Ellis 


\section{Parasitology}

EDITOR-IN-CHIEF

R. S. PHILLIPS

EDITOR - SPECIAL ISSUES

J. T. ELLIS

EDITORS

A. BELL, A. HEMPHILL, L. RINALDI, J. R. STOTHARD, J. WASTLING

EDITORIAL POLICY

Parasitology publishes definitive papers on all aspects of pure and applied parasitology including biochemistry, molecular biology, immunology, genetics, ecology and physiology and also the application of new techniques, long-term epidemiology studies, advances in the understanding of life-cycles, chemotherapy and major systematic revisions. Papers should normally be full length with an explanatory introduction and detailed discussion of the findings reported. Shorter reports of particularly important findings will also be considered.

To submit papers online, go to http://mc.manuscriptcentral.com/par/

R. AROIAN, University of California, San Diego, USA

A. BOWMAN, University of Aberdeen, UK

C. BRITTON, University of Glasgow, UK

KATHARINE CARTER, University of Strathclyde, UK

KEVIN COUPER, University of Manchester, UK

M. DE NAZARÉ CORREIA SOEIRO, Fundação Oswaldo

Cruz, Brazil

PAUL DENNY, Durham University, UK

JENNY DUNN, University of Lincoln, UK

A. FENTON, University of Liverpool, UK

CAROLINE FREY, Canadian Food Inspection Agency, Saskatoon, Canada

DIANA HANSEN, The Walter and Eliza Hall Institute of Medical Research, Australia

H. HELMBY, London School of Hygiene \& Tropical Medicine, UK

G. HIDE, University of Salford, UK

ABDUL JABBAR, University of Melbourne, Australia

JOSEPH JACKSON, University of Salford, UK

M. K. JONES, Queensland Institute of Medical

Research, Australia
NADIRA KARUNAWEERA, University of Colombo, Sri Lanka

F. KATZER, Moredun Research Institute, UK

J. LACOURSE, Liverpool School of Tropical Medicine, $\mathrm{UK}$

ZHAO-RONG LUN, Sun Yat-Sen University, P.R. China

M. McALLISTER, University of Adelaide, Australia

SERGE MORAND, CNRS, ISEM, University of Montpellier, France

E. MORGAN, University of Bristol, UK

D. OUTLAW, Mississippi State University, USA

T. SCHETTERS, Intervet International, The Netherlands

U. TATU, Indian Institute of Science, India

J. T. TIMI, Universidad Nacional de Mar del Plata-CONICET, Argentina

PAUL TORGERSON, Vetsuisse Faculty, Switzerland MARK VINEY, University of Bristol, UK

R. A. WILSON, University of York, UK

ANNETTA ZINTL, University College Dublin, Ireland

Parasitology (ISSN 0031-1820) is published monthly and semi-monthly in April and September.

Subscriptions may be sent to any bookseller or subscription agent or direct to the publisher: Cambridge University Press, University Printing House, Shaftesbury Road, Cambridge CB2 8BS, UK. Subscriptions in the USA, Canada and Mexico should be sent to Cambridge University Press, Journals Fulfillment Department,

1 Liberty Plaza, Floor 20, New York, NY 10006, USA. All orders must be accompanied by payment.

The subscription price (excluding VAT) of Volume 147, 2020 which includes print and electronic access is £2024 (US $\$ 3438$ in the USA, Canada and Mexico), for fourteen parts; the electronic-only price for institutional subscribers is $£ 1619$ (US $\$ 2756$ in the USA, Canada and Mexico); separate parts cost £166 or US $\$ 282$ each (plus postage). EU subscribers (outside the UK) who are not registered for VAT should add VAT at their country's rate. VAT registered subscribers should provide their VAT registration number. Japanese prices for institutions are available from Kinokuniya Company Ltd, P.O. Box 55, Chitose, Tokyo 156, Japan. Periodicals postage paid at New York, NY and at additional mailing offices. POSTMASTER: send address changes in USA, Canada and Mexico to Parasitology, Cambridge University Press, 1 Liberty Plaza, Floor 20, New York, NY 10006, USA.

Information on back volumes, permissions and advertising is given on the inside back cover.

The Journal is listed in the major relevant abstracting and indexing services worldwide, including Abstracts on Hygiene and Communicable Disease, Biological Abstracts, Biotechnology Research Abstracts, Chemical Abstracts,

Current Awareness in Biological Science, Current Contents, Dairy Science Abstracts, Excerpta Medica, Helminthological Abstracts, Index Medicus, Index Veterinarius, IABS, Protozoological Abstracts, Reviews of Applied Entomology, Tropical Diseases Bulletin, Veterinary Bulletin.

Information on Parasitology and all other Cambridge journals can be accessed via journals.cambridge.org.

This journal issue has been printed on FSC-certified paper and cover board. FSC is an independent, non-governmental, not-for-profit organization established to promote the responsible management of the world's forests.

Please see www.fsc.org for information. 